\title{
Pre-Exposure Prophylaxis Counseling in a Community Sexual Health Clinic for Men Who Have Sex with Men in Lisbon, Portugal
}

\section{Aconselhamento de Profilaxia Pré-Exposição numa Clínica de Saúde Sexual para Homens Que Têm Sexo com Homens em Lisboa, Portugal}

\author{
Sofia RIBEIRO $\mathbb{1}^{1,2}$, Miguel ROCHA ${ }^{3}$
}

Acta Med Port 2019 Jun;32(6):441-447 - https://doi.org/10.20344/amp.11474

\section{ABSTRACT}

Introduction: Pre-exposure prophylaxis is defined as the use of antiretroviral drugs to prevent HIV acquisition in uninfected individuals. Recognizing the increasing use of informal pre-exposure prophylaxis in Portugal, CheckpointLX, a community clinic targeted to men who have sex with men in Lisbon, Portugal, began offering counselling and follow-up services prior to formal introduction. This study aims to characterize pre-exposure prophylaxis users attending Checkpoint $L X$ before formal pre-exposure prophylaxis introduction in Portugal, and those who were referred to pre-exposure prophylaxis in the National Health Service following formal approval of pre-exposure prophylaxis.

Material and Methods: Data was collected by peer counsellors between May 2015 and September 2018 and inserted in a database. Medical care followed the European AIDS Clinical Society recommendations for pre-exposure prophylaxis eligibility, initiation and follow-up. For formal pre-exposure prophylaxis, the General-Directorate for Health's Pre-exposure Prophylaxis guidelines checklist was used.

Results: Until the end of May 2018, CheckpointLX had a total of 90 appointments for wild pre-exposure prophylaxis, of which 64 (71\%) were first time visits. As for the 380 service users referred to the National Health Service, most were Portuguese $(n=318,84 \%)$, and the mean age was 31 (8.9) years old. Condomless sex in the last six months with partners of unknown HIV status was the most common eligibility criteria $(n=59,83 \%)$.

Discussion: Pre-exposure prophylaxis delivery should be complemented with effective information on the importance of immunization and education on safer practices of drug administration, in the scope of broader preventive sexual health care.

Conclusion: Much remains to be done in Portugal to ensure that pre-exposure prophylaxis is available to those who need it the most. Offering pre-exposure prophylaxis at community clinics could be a first step.

Keywords: Counseling; HIV Infections/prevention \& control; Homosexuality, Male; Pre-Exposure Prophylaxis; Sexual Behavior

\section{RESUMO}

Introdução: A profilaxia pré-exposição pode ser definida como o uso de medicamentos anti-retrovirais para prevenir a aquisição do VIH em indivíduos não infectados. Reconhecendo o uso crescente da profilaxia pré-exposição informal em Portugal, o CheckpointLX, uma clínica comunitária destinada a homens que têm sexo com homens em Lisboa, Portugal, começou a oferecer aconselhamento e serviços de acompanhamento antes da introdução formal. Este estudo pretende caracterizar os utilizadores da profilaxia pré-exposição que frequentam o CheckpointLX antes da introdução formal da profilaxia pré-exposição em Portugal, e aqueles que foram encaminhados para a profilaxia pré-exposição no Serviço Nacional de Saúde após a aprovação formal da profilaxia pré-exposição.

Material e Métodos: Os dados foram colhidos por pares entre maio de 2015 e setembro de 2018 e inseridos numa base de dados. Os cuidados médicos seguiram as recomendações da European AIDS Clinical Society para elegibilidade, iniciação e acompanhamento da profilaxia pré-exposição. Para a profilaxia pré-exposição formal, foi utilizada a lista de verificação da Norma de Profilaxia Pré-exposição da Direção-Geral da Saúde.

Resultados: Até ao final de maio de 2018, o CheckpointLX fez um total de 90 consultas para o wild pre-exposure prophylaxis, das quais $64(71 \%)$ foram primeiras consultas. Quanto aos 380 utilizadores referenciados ao Serviço Nacional de Saúde, a maioria era de nacionalidade portuguesa $(n=318,84 \%)$ e a idade média era de $31(8,9)$ anos. Sexo sem preservativo nos últimos seis meses com parceiros com estatuto VIH desconhecido foi o critério de elegibilidade mais reportado $(n=59,83 \%)$.

Discussão: A dispensa da profilaxia pré-exposição deve ser complementada com informações eficazes sobre a importância da imunização e da educação em práticas mais seguras de administração de medicamentos, no âmbito de cuidados de saúde sexual preventivos mais amplos.

Conclusão: Ainda há muito a ser feito em Portugal para garantir que a profilaxia pré-exposição esteja disponível para aqueles que mais dela precisam. Oferecer profilaxia pré-exposição em clínicas comunitárias pode ser um primeiro passo.

Palavras-chave: Aconselhamento; Comportamento Sexual; Homossexualidade Masculina; Infecções por VIH/prevenção e controlo; Profilaxia Pré-Exposição

\footnotetext{
1. Department of International Health. Care and Public Health Research Institute (CAPHRI). Maastricht University. Maastricht. The Netherlands.

2. Grupo de Ativistas em Tratamentos. Lisbon. Portugal.

3. CheckpointLX. Grupo de Ativistas em Tratamentos. Lisbon. Portugal.

$\square$ Autor correspondente: Sofia Ribeiro. sofia.ribeiro@gatportugal.org

Recebido: 24 de outubro de 2018 - Aceite: 26 de fevereiro de 2019 | Copyright @ Ordem dos Médicos 2019
} 
INTRODUCTION

Pre-exposure prophylaxis (PrEP) is defined as the use of antiretroviral drugs to prevent human immunodeficiency virus (HIV) acquisition by uninfected individuals. ${ }^{1}$ The high efficacy of oral PrEP in both continuous and event-driven regimens has been demonstrated in several trials, ${ }^{2-8}$ as has its cost-effectiveness with each avoided infection..$^{9,10}$

In 2015 the World Health Organization (WHO) recommended PrEP as a prevention tool for serodiscordant couples, transgender women and men who have sex with men at high risk of HIV ${ }^{11}$ after first publishing guidance on PrEP use in demonstration projects in 2012 - the same year the Food and Drug Administration (FDA) approved emtricitabine/tenofovir disoproxil fumarate for PrEP in the USA. ${ }^{12}$

Formal introduction of PrEP in the European Union was led by France in December 2015, with authorization and full reimbursement for people at high risk of acquiring HIV, and the launch of hospital-based PrEP consultations in Paris in January 2016. ${ }^{13}$ Norway, Scotland and Belgium soon joined France in implementing PrEP delivery across their respective national health services (NHS). A second group of countries began providing PrEP within the scope of small demonstration projects, which are currently at full recruiting capacity (e.g. England and Spain). ${ }^{14} \mathrm{~A}$ third group of countries made the medicines for PrEP available at community pharmacies, but struggle with warranting reimbursement by insurers (e.g. Netherlands and Germany). ${ }^{14}$

Portugal approved PrEP on the $2^{\text {nd }}$ June 2017, under the terms of Dispatch 4835/2017 of the Deputy Secretary of Health, ${ }^{15}$ joining France's model of provision from the NHS. On the $28^{\text {th }}$ November 2017 the General Directorate for Health published a novel clinical guideline on PrEP, ${ }^{16}$ stipulating that people at increased risk of acquiring HIV be referred to a hospital specialist within 30 days. On the $21^{\text {st }}$ February 2018 the National Authority of Medicines and Health Products, (INFARMED) approved an Early Access Program for the provision of emtricitabine/tenofovir disoproxil fumarate for use in association with safer sex practices as PrEP, free of charge in the NHS, in order to accelerate access to these medicines in the anticipation of the still ongoing reimbursement approval process. ${ }^{17}$ The first patient appointment for PrEP took place on the $12^{\text {th }}$ April 2018, 11 months after its ministerial approval. At the moment of publication, PrEP was available in 6 of the 44 Portuguese NHS hospitals, in the cities of Almada, Lisbon, Loures and Porto, some of which have been unable to comply with the maximum compulsory 30-day response period. PrEP is not available for migrant citizens not yet enrolled in the NHS.

PrEP was informally in use in European countries prior to formal introduction, and outside the context of clinical trials and demonstration projects, in a still ongoing phenomena dubbed 'Wild PrEP', resembling the antiretroviral buyers' clubs of the 1980s. ${ }^{18-25}$ Medicines for PrEP can currently be obtained informally in several ways: by ordering them online; by purchasing them where the medicines are available over the counter; by seeking faux post-exposure prophylaxis (PEP) care; ${ }^{23}$ or by using medicines prescribed to people living with HIV. Informal PrEP poses significant challenges for health care professionals and health services, as it does not ensure access to adequate follow up, ${ }^{26}$ and it is difficult to control the quality of medicines ordered online, which can in extremis result in the user acquiring an HIV infection.

Studies published in recent years have provided valuable insights into the factors underlying PrEP use, showing delivery models play a considerable role in shaping the strategy's success. Interventions have been considered more effective when offered in combination with comprehensive prevention approaches, ${ }^{1}$ and the use of a wide range of health care professionals has also been shown to improve medication adherence. ${ }^{27}$ Furthermore, studies suggest PrEP services should be planned with consideration for user preferences, namely by offering them at convenient times and in welcoming settings, such as Public Health Services or STI clinics with experience regarding PrEP care and cultural awareness in dealing with vulnerable populations. ${ }^{28}$

Few healthcare services in Portugal cater to the needs of the populations at most risk of acquiring HIV. CheckpointLX is a community-based sexual health center managed by Grupo de Ativistas em Tratamentos/Group of Activists in Treatments (GAT), a non-governmental organization that advocates for legal and political reforms that drive positive changes for people living with HIV and for those at risk of acquiring the infection. CheckpointLX is one of the few STI clinics targeted at MSM in Portugal, working as a low threshold walk-in clinic offering rapid testing for blood-borne viruses and syphilis, and as an outpatient clinic for screening and treatment of other STIs. While other STI clinics exist, they target the general population, which some regard as an access barrier to MSM sexual health services for fear of stigma and discrimination.

On May 12 2015, recognizing the increasing use of informal PrEP, CheckpointLX began offering counselling and follow-up services for MSM prior to formal introduction. When PrEP was approved in Portugal, CheckpointLX continued to offer counselling for PrEP with the aim of screening high risk HIV negative MSM and referring them to PrEP in the NHS.

This study aims to characterize PrEP users attending CheckpointLX before formal PrEP introduction in Portugal, and those who were referred to PrEP in the NHS after screening at CheckpointLX.

\section{MATERIAL AND METHODS}

Data were collected by qualified peer counsellors and inserted in a database, including sociodemographic data, behavioral characteristics, immunization and prior STI testing records, and other data connected with PrEP follow up. ${ }^{29}$ Medical care followed European AIDS Clinical Society (EACS) recommendations for PrEP eligibility, initiation and follow up. For formal PrEP, the General-Directorate for Health's PrEP guidelines checklist was used. ${ }^{28}$ Table 1 summarizes the criteria of this checklist, as well as other clinical evaluation and preventive measures to be taken prior to PrEP initiation. 
Table 1 - Portuguese General-Directorate for Health's PrEP guidelines checklist (adapted from the PrEP guideline)

\begin{tabular}{l} 
All criterion of eligibility (as per General-Directorate for Health guideline) \\
Condomless sex in the last six months with partner of unknow HIV status \\
Condomless sex and an STI diagnosis in the last six months \\
Condomless sex and PEP use in the last six months \\
Sex under the influence of alcohol or drugs \\
Sex in order to get money, goods or drugs \\
\hline Clinical evaluation and preventive measures prior to PrEP consideration \\
\hline Assessment of the increased risk of acquiring HIV and other STls \\
Definition of a prevention plan for HIV and other STIs \\
Availability of condoms and referral to specific support programs, when indicated \\
Assessment of the person's knowledge about PrEP, its motivation and adherence \\
Evaluation of the existence of co-morbidities that may contraindicate the onset of PrEP on the presence of signs or symptoms \\
suggestive of acute phase HIV infection \\
Collection of concomitant drug history and risk assessment of potential pharmacological interactions \\
$4^{\text {th }}$ generation serological test anti HIV1/2 plus Ag p24 on the same day or at most up to 7 days before the start of PrEP \\
i. in case of suspected acute infection, HIV-1 viral load should be prescribed and performed \\
ii. only individuals with negative results should be eligible for PrEP \\
STI screening \\
Assessment of serological status for hepatitis A, hepatitis B, hepatitis C and immunization or treatment where indicated \\
Evaluation of indication of immunization for human papillomavirus (HPV) \\
\hline
\end{tabular}

STI screening was subsequently performed, as indicated in the clinical guideline. Appropriate samples were collected for point of care rapid testing for HIV, syphilis, hepatitis B and C, and for laboratory testing of other STIs, including gonorrhea, chlamydia, lymphogranuloma venereum, mycoplasma genitalium, human papilloma virus (HPV) and anal intraepithelial neoplasia. Men who returned for follow up were offered STI retesting at 3-month intervals or as appropriate.

For the purpose of this study, we considered two populations: Wild PrEP (data collected from May 2015 until May 2018) and formal PrEP (data collected from May 2018 to September 2018). Between April and May there was an overlap for both populations.

Data collection and utilization were authorized by the Portuguese Data Protection Commission (authorization no.3207/2017). Data were analyzed using STATA(R) version 13.

\section{RESULTS}

From May 2015 until the end of May 2018, prior to the introduction of formal PrEP in Portugal, CheckpointLX had a total of 90 appointments for Wild PrEP, of which 64 $(71 \%)$ were first time visits and the remaining were follow up visits. Most service users were born in Portugal $(n=41$, $64 \%$ ), while $7(11 \%)$ were from Brazil. The mean age was 40 years old (SD 9.5 years) and almost all $(n=58,91 \%)$ self-identified as homosexual. With regards to immunization status, $41(64 \%)$ were vaccinated against Hepatitis B virus at admission, $24(38 \%)$ were vaccinated against Hepatitis A virus and $7(11 \%)$ were vaccinated against Human Papillo- ma Virus with either quadrivalent or 9-valent vaccines. Out of the the total, $24(38 \%)$ had a self-reported history of an STI in the past 12-month period, syphilis being the most common $(n=9,38 \%)$. Most $(n=40,63 \%)$ reported more than 10 sexual partners over the past 12 -month period, and $35(55 \%)$ had at least one instance of sex with multiple partners in the same period. Inhaled drug use was reported by $33(52 \%)$ service users. Table 2 summarizes the baseline characteristics of service users in follow-up of 'Wild PrEP' at CheckpointLX.

As for the 380 service users referred to the NHS following formal introduction of PrEP, most were Portuguese $(n=318,84 \%)$, and the mean age was 31 (8.9) years old. Eligibility criteria was available for a subset of 71 users, $58 \%$ of whom fulfilled 1 criterion only, followed by $30 \%$ who fulfilled 2 criteria. Condomless sex in the last six months with partners of unknown HIV status was the most common eligibility criteria ( $n=59,83 \%$ ), followed by sex under the influence of alcohol and drugs $(n=25,35 \%)$. Table 3 shows the baseline characteristics of users referred to PrEP in the NHS from April 2018 to September 2018.

\section{DISCUSSION}

CheckpointLX's three-year long experience providing follow up medical care for Wild PrEP users represents an invaluable opportunity to study this population closely and learn more about their needs and requirements.

A total of $97 \%$ of Wild PrEP users had been tested for HIV in the past three months, showing most were seeking follow up care at adequate intervals. $38 \%$ had an STI diagnosis in the past 12 -month period, $63 \%$ reported having 
Table 2 - Baseline characteristics of service users in follow-up of 'Wild PrEP' at CheckpointLX, May 2015 to May 2018

\begin{tabular}{|c|c|c|}
\hline \multicolumn{3}{|c|}{ Baseline characteristics of service users in follow up of 'Wild PrEP' at CheckpointLX $(n=64)$} \\
\hline Variable & $\mathbf{n}$ & $\%$ \\
\hline \multicolumn{3}{|l|}{ Socio-demographics } \\
\hline Country of birth & $\mathbf{n}$ & $\%$ \\
\hline $\begin{array}{l}\text { Portugal } \\
\text { Brazil } \\
\text { Other }\end{array}$ & $\begin{array}{c}41 \\
7 \\
16\end{array}$ & $\begin{array}{l}64 \% \\
11 \% \\
25 \%\end{array}$ \\
\hline Gender identity & $\mathbf{n}$ & $\%$ \\
\hline Male & 64 & $100 \%$ \\
\hline Age & Median (range) & Mean (SD) \\
\hline Age & $41(21-60)$ & $40(9.5)$ \\
\hline Sexual orientation & $\mathbf{n}$ & $\%$ \\
\hline $\begin{array}{l}\text { Bisexual } \\
\text { Homosexual } \\
\text { Information not available }\end{array}$ & $\begin{array}{c}4 \\
58 \\
2\end{array}$ & $\begin{array}{c}6 \% \\
91 \% \\
3 \%\end{array}$ \\
\hline \multicolumn{3}{|l|}{ Kidney function } \\
\hline Creatinine clearance at admission & $\mathbf{n}$ & $\%$ \\
\hline $\begin{array}{l}0-50 \\
51-60 \\
61-90 \\
91-150 \\
\text { Information not available }\end{array}$ & $\begin{array}{c}0 \\
0 \\
3 \\
3 \\
58\end{array}$ & $\begin{array}{c}0 \% \\
0 \% \\
5 \% \\
5 \% \\
91 \%\end{array}$ \\
\hline Proteinuria at admission & $\mathbf{n}$ & $\%$ \\
\hline $\begin{array}{l}\text { YES } \\
\text { NO } \\
\text { Information not available }\end{array}$ & $\begin{array}{c}1 \\
7 \\
56\end{array}$ & $\begin{array}{l}2 \% \\
11 \% \\
88 \%\end{array}$ \\
\hline \multicolumn{3}{|l|}{ Immunizations } \\
\hline Vaccinated for HBV at admission & $\mathbf{n}$ & $\%$ \\
\hline $\begin{array}{l}\text { YES } \\
\text { NO } \\
\text { UNSURE } \\
\text { Information not available }\end{array}$ & $\begin{array}{c}41 \\
7 \\
7 \\
9\end{array}$ & $\begin{array}{l}64 \% \\
11 \% \\
11 \% \\
14 \%\end{array}$ \\
\hline Vaccinated for HAV at admission & $\mathbf{n}$ & $\%$ \\
\hline $\begin{array}{l}\text { YES } \\
\text { NO } \\
\text { UNSURE } \\
\text { Information not available }\end{array}$ & $\begin{array}{c}24 \\
27 \\
4 \\
9\end{array}$ & $\begin{array}{c}38 \% \\
42 \% \\
6 \% \\
14 \%\end{array}$ \\
\hline Vaccinated for HPV at admission & $\mathbf{n}$ & $\%$ \\
\hline $\begin{array}{l}\text { YES } \\
\text { NO } \\
\text { UNSURE } \\
\text { Information not available }\end{array}$ & $\begin{array}{c}7 \\
46 \\
2 \\
9\end{array}$ & $\begin{array}{c}11 \% \\
72 \% \\
3 \% \\
14 \%\end{array}$ \\
\hline \multicolumn{3}{|l|}{ STI history } \\
\hline Last HIV test (in months) & $\mathbf{n}$ & $\%$ \\
\hline $\begin{array}{l}0-1 \\
1-3 \\
3-6 \\
6-12\end{array}$ & $\begin{array}{c}44 \\
18 \\
1 \\
1\end{array}$ & $\begin{array}{c}69 \% \\
28 \% \\
2 \% \\
2 \%\end{array}$ \\
\hline STI history in past 12 -month period & $\mathbf{n}$ & $\%$ \\
\hline $\begin{array}{l}\text { YES } \\
\text { chlamydia } \\
\text { gonorrhea } \\
\text { syphilis } \\
\text { other STI } \\
\text { NO }\end{array}$ & $\begin{array}{c}24 \\
5 \\
3 \\
9 \\
9 \\
40\end{array}$ & $\begin{array}{l}38 \% \\
21 \% \\
13 \% \\
38 \% \\
38 \% \\
63 \%\end{array}$ \\
\hline
\end{tabular}


Table 2 (cont.) - Baseline characteristics of service users in follow-up of 'Wild PrEP' at CheckpointLX, May 2015 to May 2018

$\begin{array}{lcc}\text { STI symptoms in past 12-month period } & \mathbf{n} & \% \\ \text { YES } & 24 & 38 \% \\ \text { NO } & 40 & 63 \%\end{array}$

NO

40

$63 \%$

\section{Sexual practices}

Number of sexual partners in past 12-month period

$1-10$

$10+$

\begin{tabular}{|c|c|}
\hline $\mathbf{n}$ & $\%$ \\
\hline $\begin{array}{l}24 \\
40\end{array}$ & $\begin{array}{l}38 \% \\
63 \%\end{array}$ \\
\hline $\mathbf{n}$ & $\%$ \\
\hline $\begin{array}{c}8 \\
7 \\
49\end{array}$ & $\begin{array}{l}13 \% \\
11 \% \\
77 \%\end{array}$ \\
\hline $\mathbf{n}$ & $\%$ \\
\hline $\begin{array}{c}15 \\
47 \\
2\end{array}$ & $\begin{array}{c}23 \% \\
73 \% \\
3 \%\end{array}$ \\
\hline$n$ & $\%$ \\
\hline $\begin{array}{l}35 \\
29\end{array}$ & $\begin{array}{l}55 \% \\
45 \%\end{array}$ \\
\hline $\mathbf{n}$ & $\%$ \\
\hline $\begin{array}{c}44 \\
13 \\
7\end{array}$ & $\begin{array}{l}69 \% \\
20 \% \\
11 \%\end{array}$ \\
\hline $\mathbf{n}$ & $\%$ \\
\hline $\begin{array}{l}35 \\
29\end{array}$ & $\begin{array}{l}55 \% \\
45 \%\end{array}$ \\
\hline $\mathrm{n}$ & $\%$ \\
\hline $\begin{array}{l}13 \\
51\end{array}$ & $\begin{array}{l}20 \% \\
80 \%\end{array}$ \\
\hline $\mathbf{n}$ & $\%$ \\
\hline 40 & $63 \%$ \\
\hline 24 & $38 \%$ \\
\hline
\end{tabular}

Role in anal intercourse

Insertive

Receptive

Both

Consistent condom use in anal intercourse

YES

NO

Information not available

Ejaculation in mouth

YES

NO

\section{Oral-anal sex}

YES

NO

Information not available

Sex with multiple partners

YES

NO

\section{Fisting}

YES

NO

(

Douching

YES

NO

\begin{tabular}{cc}
$\mathbf{n}$ & $\%$ \\
3 & $5 \%$ \\
61 & $95 \%$ \\
$\mathbf{n}$ & $\%$ \\
33 & $52 \%$ \\
31 & $48 \%$ \\
\hline
\end{tabular}

\section{Substance use}

Report injected drug use

YES

NO

Report inhaled drug use

YES

31

NO

needed, such as education regarding safer practices of

10 or more sexual partners and $73 \%$ reported inconsistent condom use in the same period, attesting to their high risk of acquiring HIV. This last item was similar in users referred to formal PrEP, $83 \%$ of whom reported instances of condomless sex in the last six months with people of unknown HIV status as their main criteria for seeking PrEP.

While a good number of users were immunized against Hepatitis B $(64 \%)$, only a fraction was immunized against Hepatitis A (38\%) or HPV (11\%). Considering this population's highest risk of infection with both viruses and recent viral hepatitis outbreaks in Europe, including Portugal, ${ }^{30}$ it is crucial to complement PrEP delivery with effective information regarding the importance of immunization in the scope of broader preventive sexual health care. Given that $52 \%$ reported inhaled drug use in the past 12-month period, it is safe to assume harm reduction interventions are also drug use.

A total of $36 \%$ of CheckpointLX's Wild PrEP users are foreign citizens living in Portugal, yet only $16 \%$ of those referred for formal PrEP in the NHS were foreign citizens. There is enough data to show an unmet need in providing formal PrEP for migrant citizens. Including these citizens in any future update to public health policy will be crucial, for risk of failure of the strategy, as borders may apply to provision but not to disease control.

This study has some limitations which should be mentioned. One is recall bias, as participants might not remember accurately all the information that is asked to them during the interview. The interviewer bias is also to consider: the respondents might want to please the interviewer by giving him the information they consider appropriate. External 
Table 3 - Baseline characteristics of service users referred to PrEP in the NHS through CheckpointLX, April 2018 to September 2018

\begin{tabular}{|c|c|c|}
\hline \multicolumn{3}{|c|}{ Baseline characteristics of service users referred to PrEP in the NHS through CheckpointLX $(n=380)$} \\
\hline Variable & $\mathbf{n}$ & $\%$ \\
\hline \multicolumn{3}{|l|}{ Socio-demographics } \\
\hline Country of birth & $\mathbf{n}$ & $\%$ \\
\hline $\begin{array}{l}\text { Portugal } \\
\text { Brazil } \\
\text { Spain } \\
\text { Other }\end{array}$ & $\begin{array}{c}318 \\
34 \\
5 \\
6\end{array}$ & $\begin{array}{l}84 \% \\
9 \% \\
1 \% \\
6 \%\end{array}$ \\
\hline Age & Median (range) & Mean (SD) \\
\hline Age & $33(17-61)$ & $31(8,9)$ \\
\hline \multicolumn{3}{|l|}{ Eligibility (data available for a subset of 71 users) } \\
\hline Number for criteria of eligibility (per DGS guideline) & $\mathbf{n}$ & $\%$ \\
\hline $\begin{array}{l}\text { Service users fulfilling } 1 \text { criterion } \\
\text { Service users fulfilling } 2 \text { criteria } \\
\text { Service users fulfilling } 3 \text { criteria } \\
\text { Service users fulfilling } 4 \text { criteria }\end{array}$ & $\begin{array}{l}41 \\
21 \\
7 \\
2\end{array}$ & $\begin{array}{l}58 \% \\
30 \% \\
10 \% \\
3 \%\end{array}$ \\
\hline Main criterion of eligibility (per DGS guideline) & $\mathbf{n}$ & $\%$ \\
\hline $\begin{array}{l}\text { Condomless sex in the last six months with people of unknow HIV status } \\
\text { Condomless sex and an STI diagnosis in the last six months } \\
\text { Condomless sex and PEP use in the last six months } \\
\text { Sex under the influence of alcohol or drugs }\end{array}$ & $\begin{array}{c}59 \\
1 \\
3 \\
8\end{array}$ & $\begin{array}{c}83 \% \\
1 \% \\
4 \% \\
11 \%\end{array}$ \\
\hline All criterion of eligibility (per DGS guideline) & $\mathbf{n}$ & $\%$ \\
\hline $\begin{array}{l}\text { Condomless sex in the last six months with people with unknow HIV status } \\
\text { Condomless sex and an STI diagnosis in the last six months } \\
\text { Condomless sex and PEP use in the last six months } \\
\text { Sex under the influence of alcohol or drugs } \\
\text { Sex in order to get money, goods or drugs } \\
\text { Cumulative vulnerability and possibility of having sex (without a condom) against their will }\end{array}$ & $\begin{array}{c}59 \\
13 \\
8 \\
25 \\
3 \\
4\end{array}$ & $\begin{array}{l}83 \% \\
18 \% \\
11 \% \\
35 \% \\
4 \% \\
6 \%\end{array}$ \\
\hline
\end{tabular}

validity of this study might be limited due to the fact that participants are recruited might not be representative of the MSM population in Lisbon.

Even though efforts have been made towards offering PrEP to the Portuguese population, much remains to be done to ensure that PrEP is available to those in need. A study conducted by the CDC using a national representative sample from the United States of America estimated that $24.5 \%$ of sexually active MSM, $18.5 \%$ of people who inject drugs and $0.4 \%$ of sexually active heterosexual individuals were eligible for PrEP. ${ }^{31}$ According to data from the Lisbon MSM cohort ( $n=5,447$ ), a variable number of MSM would be eligible for PrEP in Portugal: 2485 (45.6\%) according to EACS 2017 guidelines, 2929 (53.8\%), according to WHO 2017 guidelines, and 3556 (65.3\%) according to CDC 2014 guidelines. ${ }^{33}$ This is far above the current capacity of the Portuguese NHS, which demonstrates the scale up and diversification need of the current pilot.

PrEP should also be made available at the community level, as a complement to hospital delivery, as it can increase the availability and uptake of PrEP. A combination of other key elements for successful PrEP implementation have been identified by a review on PrEP implementation in early adopting countries and should be considered in Portugal. ${ }^{34}$ These include: knowledge of the epidemiology and patterns of HIV transmission, determination of the facilities which are best equipped for PrEP delivery, community engagement, institutional leadership, training of providers and the community and adequate access to related health services, including STI screening and management, harm reduction programs and behavioral health interventions.

\section{CONCLUSION}

To the best of our knowledge, our study is the first to describe the use of PrEP in MSM in Portugal, providing an overview of the use of Wild PrEP and also the use of PrEP following the formal introduction of PrEP in the NHS. Despite recent steps to implement PrEP in Portugal, much remains to be done to ensure adequate access and follow up for those who stand to benefit most from this prevention strategy, namely: scale up of capacity, diversification of sites of PrEP care provision, inclusion of migrant citizens, investment in harm reduction and in vaccination.

\section{ACKNOWLEDGEMENTS}

The authors would like to thank the staff working at GAT, especially at CheckpointLX, and the Instituto de Saúde Pública da Universidade do Porto (ISPUP) for the support given in the elaboration of this manuscript.

\section{PROTECTION OF HUMANS AND ANIMALS}

The authors declare that the procedures were followed according to the regulations established by the Clinical Research and Ethics Committee and to the Helsinki Declaration of the World Medical Association. 


\section{DATA CONFIDENTIALITY}

The authors declare having followed the protocols in use at their working center regarding patients' data publication.

\section{CONFLICTS OF INTEREST}

All authors report no conflict of interest.

\section{REFERENCES}

1. Cremin I, Alsallaq R, Dybul M, Piot P, Garnett G, Hallett TB. The new role of antiretrovirals in combination HIV prevention. AIDS. 2013;27:447-58.

2. Grant RM, Lama JR, Anderson PL, McMahan V, Liu AY, Vargas L, et al. Preexposure chemoprophylaxis for HIV prevention in men who have sex with men. N Engl J Med. 2010;363:2587-99.

3. Baeten JM, Donnell D, Ndase P, Mugo NR, Campbell JD, Wangisi J, et al. Antiretroviral prophylaxis for HIV prevention in heterosexual men and women. N Engl J Med. 2012;367:399-410.

4. Brooks RA, Landovitz RJ, Kaplan RL, Lieber E, Lee S-J, Barkley TW. Sexual risk behaviors and acceptability of HIV pre-exposure prophylaxis among HIV-negative gay and bisexual men in serodiscordant relationships: a mixed methods study. AIDS Patient Care STDS. 2012;26:87-94.

5. Thigpen MC, Kebaabetswe PM, Paxton LA, Smith DK, Rose CE, Segolodi TM, et al. Antiretroviral preexposure prophylaxis for heterosexual HIV transmission in Botswana. N Engl J Med. 2012;367:423-34.

6. Molina JM, Capitant C, Spire B, Pialoux G, Cotte L, Charreau I, et al. Ondemand preexposure orophylaxis in men at high risk for HIV-1 infection. N Engl J Med. 2015;373:2237-46.

7. Fonner VA, Dalglish SL, Kennedy CE, Baggaley R, O'Reilly KR, Koechlin $\mathrm{FM}$, et al. Effectiveness and safety of oral HIV preexposure prophylaxis for all populations. AIDS. 2016;30:1973-83.

8. McCormack S, Dunn DT, Desai M, Dolling DI, Gafos M, Gilson R, et al. Pre-exposure prophylaxis to prevent the acquisition of HIV-1 infection (PROUD): effectiveness results from the pilot phase of a pragmatic open-label randomised trial. Lancet. 2016;387:53-60.

9. Jacobsen MM, Walensky RP. Modeling and cost-effectiveness in HIV prevention. Curr HIVIAIDS Rep. 2016;13:64-75.

10. Schackman BR, Fleishman JA, Su AE, Berkowitz BK, Moore RD, Walensky RP, et al. The lifetime medical cost savings from preventing HIV in the United States. Med Care. 2015;53:1.

11. World Health Organization. Guidance on oral pre-exposure prophylaxis (PrEP) for serodiscordant couples, men and transgender women who have sex with men at high risk of HIV. Geneve: WHO; 2015;

12. World Health Organization. Guidance on pre-exposure oral prophylaxis (PrEP) for serodiscordant couples, men and transgender women who have sex with men at high risk of HIV : recommendations for use in the context of demonstration projects. Geneve: WHO; 2012.

13. Rivierez I, Quatremere G, Spire B, Ghosn J, Rojas Castro D. Lessons learned from the experiences of informal PrEP users in France: results from the ANRS-PrEPage study. AIDS Care. 2018;30:S48-53.

14. ECDC. HIV and men who have sex with men Monitoring implementation of the Dublin Declaration on Partnership to Fight HIVIAIDS in Europe and Central Asia: 2017 progress report HIV and men who have sex with men. 2017. [cited 2018 Oct 22]. Available from: https://ecdc.europa.eu/ sites/portal/files/documents/HIV and men who have sex with men.pdf.

15. Gabinete do Secretário de Estado Adjunto e da Saúde. Despacho n. ${ }^{\circ}$ 4835/2017. 2017. Lisboa: Ministério da Saúde; 2017.

16. Direção Geral da Saúde. Norma 025/2017. Profilaxia de pré-exposição da infecção por VIH no adulto. Lisboa: DGS; 2017.

17. Circular normativa conjunta N. ${ }^{\circ}$ 02/2018/INFARMED/ACSS/DGS/ SPMS. Programa de Acesso Precoce para Profilaxia de Pré-exposição da infecção por VIH-1 no Adulto. Lisboa: INFARMED; 2018.

18. Voetsch AC, Heffelfinger JD, Begley EB, Jafa-Bhushan K, Sullivan PS. Knowledge and use of preexposure and postexposure prophylaxis among attendees of Minority Gay Pride events, 2005 through 2006. J Acquir Immune Defic Syndr. 2007;46:378-80.

19. Leonardi M, Lee E, Tan DH. Awareness of, usage of and willingness to

\section{FUNDING SOURCES}

This research received no specific grant from any funding agency in the public, commercial, or not-for-profit sectors.

use HIV pre-exposure prophylaxis among men in downtown Toronto, Canada. Int J STD AIDS. 2011;22:738-41.

20. Holt M, Murphy DA, Callander D, Ellard J, Rosengarten M, Kippax SC, et al. Willingness to use HIV pre-exposure prophylaxis and the likelihood of decreased condom use are both associated with unprotected anal intercourse and the perceived likelihood of becoming HIV positive among Australian gay and bisexual men. Sex Transm Infect. 2012;88:258-63.

21. Krakower DS, Mimiaga MJ, Rosenberger JG, Novak DS, Mitty JA, White $\mathrm{JM}$, et al. Limited awareness and low immediate uptake of pre-exposure prophylaxis among men who have sex with men using an internet social networking site. PLoS One. 2012;7:e33119.

22. Lociciro S, Jeannin A, Dubois-Arber F. Men having sex with men serosorting with casual partners: who, how much, and what risk factors in Switzerland, 2007-2009. BMC Public Health. 2013;13:839.

23. Zablotska IB, Prestage G, de Wit J, Grulich AE, Mao L, Holt M. The Informal use of antiretrovirals for preexposure prophylaxis of HIV infection among gay men in Australia. J Acquir Immune Defic Syndr. 2013;62:334-8.

24. Rosenthal E, Piroth L, Cua E, Joulié A, Ravaux I, Chauveau M, et al Preexposure prophylaxis (PrEP) of HIV infection in France: a nationwide cross-sectional study (PREVIC study). AIDS Care. 2014;26:176-85.

25. Palummieri A, De Carli G, Rosenthal É, Cacoub P, Mussini C, Puro V, et al. Awareness, discussion and non-prescribed use of HIV preexposure prophylaxis among persons living with HIVIAIDS in Italy: a Nationwide, cross-sectional study among patients on antiretrovirals and their treating HIV physicians. BMC Infect Dis. 2017;17:734.

26. Brisson J. Ethical public health issues for the use of informal PrEP. Glob Public Health. 2018;13:1382-7.

27. CDC. Preexposure prophylaxis for the prevention of HIV infection in the United States - 2017 Update Clinical Practice Guideline [Internet]. 2017. [cited 2018 Oct 22]. Available from: https://www.cdc.gov/std/ $\operatorname{tg} 2015 / \operatorname{tg}-2015-$

28. Direção-Geral da Saúde. Norma 025/2017 atualizada a 16/05/2018. Profilaxia de Pré-exposição da Infeção por VIH no Adulto [Internet] 2018. [cited 2018 Oct 22]. Available from: https://www.dgs.pt/directrizesda-dgs/normas-e-circulares-normativas/norma-n-0252017-de28112017-pdf.aspx.

29. EACS. European Guidelines for treatment of HIV-positive adults in Europe version 9.0. 2017. [cited 2018 Sep 19]. Available from: http:// www.eacsociety.org/files/guidelines_9.0-english.pdf.

30. Ndumbi P, Freidl GS, Williams CJ, Mårdh O, Varela C, Avellón A, et al. Surveillance and outbreak report Members of the European Hepatitis A Outbreak Investigation Team 28. 2016. [cited 2018 Oct 22];1. Available from: http://www.ncbi.nlm.nih.gov/pubmed/30131095

31. Smith DK, Van Handel M, Wolitski RJ, Stryker JE, Hall HI, Prejean J, et al. Vital signs: estimated percentages and numbers of adults with indications for preexposure prophylaxis to prevent HIV acquisition United States, 2015. MMWR Morb Mortal Wkly Rep. 2015;64:1291-5.

32. Meireles P, Lucas R, Martins A, Carvalho AC, Fuertes R, Brito J, et al. The Lisbon cohort of men who have sex with men. BMJ Open. 2015;5.

33. Meireles P, Rocha M, Moreira C, Brito J, Mendão L, Barros H. Eligibility for pre-exposure prophylaxis in a cohort of HIV negative men who have sex with men in Lisbon, Portugal. Poster presented at the $22^{\text {nd }}$ International Workshop on HIV and Hepatitis Observational Databases. 2018.

34. Hoornenborg E, Krakower DS, Prins M, Mayer KH. Pre-exposure prophylaxis for MSM and transgender persons in early adopting countries. AIDS. 2017;31:2179-91. 